to a verification of Faxén's formula. The function used by Prof. Jauncey in arriving at (1) has the same property.

National Physical Laboratory,

G. D. Preston.

Teddington, Middlesex.

Feb. 26.

${ }^{1}$ NATURE, 147, 146 (1941).

'Proc. Roy. Soc., A, 172, 116 (1939).

\section{Influence of Estrogens and Androgens on Glycogen Storage in the Fasting Rat}

Janes and Nelson ${ }^{1}$ have observed that glycogen storage in rats treated daily with diethyl-stilbœestrol for five days or more is at an abnormally high level. We have investigated the influence of œstrogens and other sex hormones on glycogen storage; and also on the insulin content of the pancreas ( $c f$. Griffiths stances in nut-oil, an increase in liver glycogen was found to occur, in some instances, during a subsequent 30-hour fast. The results with different doses of diethyl-stilbœstrol in experiments of this type are shown in Table 2, and indicate that a single injection of $0.1 \mathrm{mgm}$. of this substance is capable of increasing the liver glycogen content of the fasting rat under such conditions. No obvious change in muscle g]ycogen content or in blood sugar level was observed in these experiments, with the possible exception of those in which $10 \mathrm{mgm}$. of diethyl-stilbœestrol was used. Again the increase in liver glycogen content was accompanied by an increase in liver size; it should be mentioned that the treated rats lost little, if any, more body-weight during the fasting period than did the control animals. CEstradiol and ostriol were found also to induce an increase in the liver glycogen content of the fasting rat under similar conditions, a property in which they resemble hormones of the adrenal cortex ${ }^{3,4}$.

These experiments show that some cestrogens can exert a profound influence on carbohydrate metabolism, inducing an increase of pancreatic insulin

TABLE 1.

INFLUENCE OF GESTROGENS AND OF TESTOSTERONE ON THE STORAGE OF GLYCOGEN AND OF INSULIN IN THE RAT.

\begin{tabular}{|c|c|c|c|c|c|c|c|}
\hline \multirow[b]{2}{*}{ Substance implanted } & \multirow[b]{2}{*}{$\begin{array}{l}\text { Number of } \\
\text { rats in group }\end{array}$} & \multirow[b]{2}{*}{$\begin{array}{l}\text { Blood sugar } \\
\text { mgm./100 c.c. }\end{array}$} & \multirow[b]{2}{*}{$\begin{array}{l}\text { Liver weight } \\
\text { gm./100 gm. } \\
\text { body weight }\end{array}$} & \multirow[b]{2}{*}{$\begin{array}{c}\text { Liver } \\
\text { glvcogen } \\
\mathrm{gm} . / 100 \mathrm{gm} .\end{array}$} & \multirow[b]{2}{*}{$\begin{array}{c}\text { Muscle } \\
\text { g]vcogen } \\
\mathrm{gm} . / 100 \mathrm{gm} .\end{array}$} & \multicolumn{2}{|c|}{ Pancreatic insulin } \\
\hline & & & & & & $\begin{array}{l}\text { u. } / 100 \mathrm{gm} . \\
\text { body weight }\end{array}$ & $\begin{array}{l}\text { Percentage } \\
\text { increment } \\
\text { above control }\end{array}$ \\
\hline Cholesterol (control) & 30 & 108 & $3 \cdot 82$ & $1 \cdot 13$ & $0 \cdot 37$ & $0 \cdot 70$ & - \\
\hline Diethyl-stilbœstrol & 30 & 109 & $5 \cdot 79$ & $2 \cdot 27$ & $0 \cdot 41$ & 0.95 & 36 \\
\hline CEstriol & 10 & 115 & $5 \cdot 13$ & $2 \cdot 32$ & 0.39 & 0.93 & 33 \\
\hline Estradiol & 10 & 113 & $4 \cdot 48$ & $1 \cdot 67$ & $0 \cdot 43$ & $1 \cdot 05$ & 50 \\
\hline Cistrone & 20 & 105 & $4 \cdot 40$ & $0 \cdot 77$ & 0.42 & $0 \cdot 68$ & nil \\
\hline Testosterone & 10 & 99 & $3 \cdot 68$ & $0 \cdot 69$ & $0 \cdot 44$ & $0 \cdot 68$ & nil \\
\hline
\end{tabular}

T. $\triangle B L E 2$.

INFLUENCE OF DIETHYL-STILBGESTROL ON GLYCOGEN STORAGE IN THE FASTING RAT.

\begin{tabular}{|c|c|c|c|c|c|c|c|c|c|c|c|c|}
\hline \multicolumn{7}{|c|}{ Treatment of rats } & $\begin{array}{l}\text { Amount } \\
\text { injected }\end{array}$ & $\begin{array}{l}\text { Number of } \\
\text { rats in group }\end{array}$ & $\begin{array}{l}\text { Blood sugar } \\
\text { mgm./100 c.c. }\end{array}$ & $\begin{array}{l}\text { Liver weight } \\
\text { gm./100 gm. } \\
\text { body weight }\end{array}$ & $\begin{array}{c}\text { Liver } \\
\text { glycogen } \\
\mathrm{gm} . / 100 \mathrm{gm} .\end{array}$ & $\begin{array}{c}\text { Mnscle } \\
\text { glycogen } \\
\text { gm. } / 100 \mathrm{gm} .\end{array}$ \\
\hline \multicolumn{3}{|c|}{ Killed initially } & & & .. & $\cdots$ & - & 30 & 97 & $2 \cdot 86$ & $0 \cdot 85$ & $0 \cdot 31$ \\
\hline \multicolumn{5}{|c|}{ Injected and fasted 30 hours } & & . & Nut oil only & 35 & 95 & $2 \cdot 87$ & 0.57 & $0 \cdot 31$ \\
\hline , & $"$ & ", & ," & , & . & $\cdots$ & $0.10 \mathrm{mgm}$. & 20 & 93 & $2 \cdot 94$ & $1 \cdot 04$ & $0 \cdot 32$ \\
\hline , & ", & ", & , & , & & $\cdots$ & $1.00 \mathrm{mgm}$. & 25 & 99 & $3 \cdot 01$ & $1 \cdot 96$ & 0.34 \\
\hline , & ", & ", & , & , & & $\cdots$ & $10.00 \mathrm{mgm}$. & 20 & 109 & $3 \cdot 98$ & $2 \cdot 04$ & $0 \cdot 30$ \\
\hline
\end{tabular}

and Young ${ }^{2}$. Data are given in Table $\mathrm{I}$, including the liver and muscle glycogen contents, after a fast of approximately $18 \mathrm{hr}$, of rats carrying subcutaneous tablets of various substances for two weeks. These results show that œstriol and œestradiol resemble diethyl-stilbœstrol in promoting glycogen storage under these conditions, although oestrone and testosterone do not. It appears that the influence of these substances on liver glycogen under such conditions is to some extent paralleled by their action in causing enlargement of the liver and an increase in pancreatic insulin ; it seems possible that the latter phenomenon is secondary to the increase in glycogen storage.

When rats were fed on cellulose for 30 hours in order to deplete the glycogen stores, and were then given a single subcutaneous injection of various sub- and a positive increase, not merely diminished loss, of liver glycogen in the fasting rat, the latter being apparently not due to a transfer of glycogen from the muscles to the liver (Table 2).

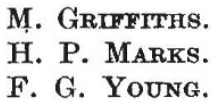

National Institute for Medical Research, London, N.W.3.

Feb. 20.

1 Janes, R. G., and Nelson, W. O., Proc. Soc. Exp. Biol. N.Y, 48 340 (1940).

2 Griffiths, M., and Young, F. G., NATURE, 146, 266 (1940).

${ }^{3}$ Britton, S. W., and Silvette, H., Amer. J. Physiol., 100, 693 (1932).

' Long, C. N. H., and Katzin, B., Proc. Soc. Exp. Biol., N.Y., 38, 516 (1938). 